\title{
IMPLEMENTATION OF REGIONAL REGULATION NUMBER 3 OF 2016 CONCERNING MANAGEMENT OF WOMEN AND CHILDREN PROTECTION IN HULU SUNGAI UTARA DISTRICT
}

\author{
AGUS SYA'BANI ARLAN \\ agussyabaniarlan@gmail.com
}

\begin{abstract}
The increasing number of Divorce each year In Hulu Sungai Utara Regency, this data is obtained based on surveys or direct observations in the Amuntai Religious Court. The number of divorce cases from 2014 was 651 cases, in 2015 it increased to 654 cases, although in 2016 and 2017 it decreased by around 601 and 622 but in 2018 this was only in September as many as 662 cases of this number, so there was an increase in divorce rates.

The purpose of this study is to identify and analyze the implementation of Regional Regulations and analyze the obstacles in implementing Regional Regulation No. 3 of 2016 concerning the Protection of Women and Children in the North Hulu Sungai Regency.

The research method is qualitative descriptive, type and source of data, namely primary data through observation, interviews while secondary data through data available at the Office of Protection and Empowerment of Women and Children in Hulu Sungai Utara Regency, the technique used in sampling is purposive sampling technique is withdrawal of samples in purpose or can be determined in accordance with the requirements (characteristics, characteristics, characteristics, criteria).

The results of the study show that in the implementation of Regional Regulation No. 3 of 2016 concerning the Implementation of Protection of Women and Children in Hulu Sungai Utara Regency, it is still not fully implemented. This can be seen where the handling of these cases has not been fully implemented, then people who are victims of domestic violence or the impact of their divorce is not all that they know about the local regulations, so they have not run properly, efficiently and effectively. So that the firmness in handling the case also cannot be implemented because the sanctions are not mentioned and the contents of the policy need to be renewed.

The suggestions given for input include, among other things, providing a place for counseling and complaints about domestic violence issues, especially for the protection of women and children, there must be attention and support from the Hulu Sungai Utara District Head regarding the issue of funding in terms of supporting treatment women's protection case.
\end{abstract}

Keywords: Implementation, Protection of Women 


\section{PENDAHULUAN}

Di Kabupaten Hulu
Sungai Utara jumlah
perceraian tiap tahunnya
bertambah, data ini didapatkan
berdasarkan survey atau
observasi langsung di
Pengadilan Agama Amuntai.
Jumlah perkara perceraian dari
tahun 2014 sebanyak 651
perkara, tahun 2015 meningkat
menjadi 654 perkara, meski di
tahun 2016 dan 2017 menurun
sekitar 601 dan 622 namun di
tahun 2018 ini baru bulan
september sebanyak 662
perkara dari jumlah ini maka
didapatlah angka peningkatan
peraian.

Kebanyakan pemohon adalah wanitanya, mereka merasa dizalimi oleh suaminya, tapi yang sangat memprihatinkan adalah buah hati mereka karena pasti mendapatkan dampak atau implikasi terhadap perpisahan ini. Pada 27 September 2018 Peneliti bertanya kepada salah satu pemohon yaitu Ibu Noorhayati yang mengatakan bahwa beliau memiliki dua orang anak yaitu laki-laki dan perempuan, yang laki-laki ikut ayah dan perempuan ikut saya katanya.

Berdasarkan dari observasi tersebut maka peneliti ingin memberikan sebuah solusi dengan bekerjasama dengan pemerintah agar melindungi anak-anak terhadap dampak dari perceraian orangtuanya. Kebijakan pemerintah dalam hal ini sangat berperan penting 


\author{
terhadap perlindungan anak- \\ anak terhadap tumbuh \\ kembangnya, jangan sampai \\ karena perceraian orangtua \\ anak jadi korban. \\ Terkait masalah tersebut \\ maka Peneliti tertarik \\ mengambil judul tentang \\ "Implementasi Peraturan \\ Daerah Nomor 3 Tahun 2016 \\ tentang Penyelengaraan \\ Perlindungan Perempuan dan \\ Anak di Kabupaten Hulu \\ Sungai Utara".
}

\section{FOKUS PENELITIAN}

Fokus penelitian yaitu mengenai kebijakan Pemerintah tentang dampak perceraian orangtua terhadap perkembangan anak. Menurut Muchlis Hamdi ( 2014:115) tentang Proses Kebijakan yaitu:
1. Perumusan Masalah Kebijakan

2. Perumusan Alternatif Kebijakan

3. Pemilihan Alternatif Kebijakan

\section{RUMUSAN MASALAH}

1. Bagaimana Implementasi Peraturan Daerah Nomor 3 Tahun 2016 tentang Penyelenggaraan

Perlindungan Perempuan dan Anak di Kabupaten Hulu Sungai Utara?

2. Apa saja hambatan yang terjadi dalam Implementasi Peraturan Daerah Nomor 3 Tahun 2016 tentang

Penyelengaraan

Perlindungan Perempuan dan Anak di Kabupaten Hulu Sungai Utara? 


\section{TUJUAN PENELITIAN}

a. Untuk mengetahui

Implementasi Peraturan

Daerah Nomor 3 Tahun

2016 tentang

Penyelenggaraan

Perlindungan Perempuan

dan Anak di Kabupeten

Hulu Sungai Utara.

b. Untuk mengidentifikasi hambatan dalam

Implementasi Peraturan

Daerah Nomor 3 Tahun

2016 tentang

Penyelenggaraan

Perlindungan Perempuan

dan Anak di Kabupaten

Hulu Sungai Utara.

\section{KONSEP KEBIJAKAN}

Secara umum,

istilah “ Kebijakan” atau "policy" (Anderson, dalam

Winarno, 2014:19) digunakan

untuk menunjuk perilaku

seorang aktor (misalnya

seorang pejabat, suatu

kelompok, maupun suatu

lembaga pemerintah) atau

sejumlah aktor dalam suatu

bisang kegiatan tertentu.

Pengertian kebijakan seperti ini dapat kita gunakan dan relatif memadai untuk keperluan pembicaraan-pembicaraan biasa, namun menjadi kurang memadai untuk pembicaraanpembicaraan yang lebih bersifat ilmiah dan sistematis yang menyangkut analisis kebijakan publik. Oleh karena itu, kita memerlukan batasan kebijakan publik yang lebih tepat.

Istilah Kebijakan publik merupakan terjemahan istilah 
Bahasa Inggris, yaitu public policy. Kata policy ada yang menerjemahkan menjadi "kebijakan” (Muhadjir Darwin dalam Sahya Anggara, 2014:35) dan ada juga yang menerjemahkan menjadi "kebijaksanaan" (Abdul Wahab dalam Sahya Anggara, 2014:35). Meskipun belum ada kesepakatan bahwa policy diterjemahkan menjadi "kebijakan" atau “kebijaksanaan", kecenderungan untuk policy digunakan istilah kebijakan. Oleh karena itu, public policy diterjemahkan menjadi kebijakan publik.

IMPLEMENTASI KEBIJAKAN PUBLIK
Keberhasilan

implementasi kebijakan akan ditentukan oleh banyak variabel atau faktor,dan masing-masing variabel tersebut saling berhubungan satu sama lain. Dalam pandangan Edwards III (dalam Subarsono, 2013:90)

implementasi kebijakan dipengaruhi oleh empat variabel, yakni (a) komunikasi, (b) sumberdaya, (c) disposisi, dan (d) struktur birokrasi. Keempat variabel tersebut juga saling berhubungan satu sama lain, yaitu sebagai berikut :

(a) Komunikasi

(b) Sumberdaya

(c) Disposisi

(d) Struktur organisasi

\section{DAMPAK}

PERCERAIAN 
Saat perceraian jadi 'solusi' bagi suami-istri, terkadang anak pun menjadi sorotan. Ada banyak kekhawatiran bahwa perceraian orang tua akan memengaruhi mental anak. Dalam studi psikologi yang dilakukan E. Mavis Hetherington dari University of Virginia dan mahasiswa Pascasarjana Anne Mitchell Elmore (internet dalam Nurvita Indarini, 25 Juli 2018), kebanyakan anak mengalami efek negatif jangka pendek dari perceraian. Saat orang tuanya baru saja bercerai, umumnya anak akan mengalami kecemasan, kemarahan, keterkejutan, dan ketidakpercayaan. penelitian mereka menyebut reaksi-reaksi negatif tersebut biasanya berkurang atau menghilang pada akhir tahun kedua. Hanya sebagian kecil anak-anak saja yang lebih lama merasakannya berkepanjangan. Demikian dikutip dari Scientific American.

Studi lainnya dilakukan sosiolog Paul R. Amato dari Pennsylvania State University (internet dalam Nurvita Indarini, 25 Juli 2018). Dia mencoba mencari tahu efek pada anak-anak setelah bertahun-tahun perceraian orang tuanya. Jadi dalam studi ini peneliti mempertimbangkan usia anak saat orang tuanya bercerai. Hasil penelitian tersebut mengungkap cuma ada sedikit perbedaan terkait prestasi akademik, masalah emosi dan perilaku, kenakalan, konsep diri dan hubungan sosial 


\section{KERANGKA BERPIKIR}

\section{Kerangka Berpikir}

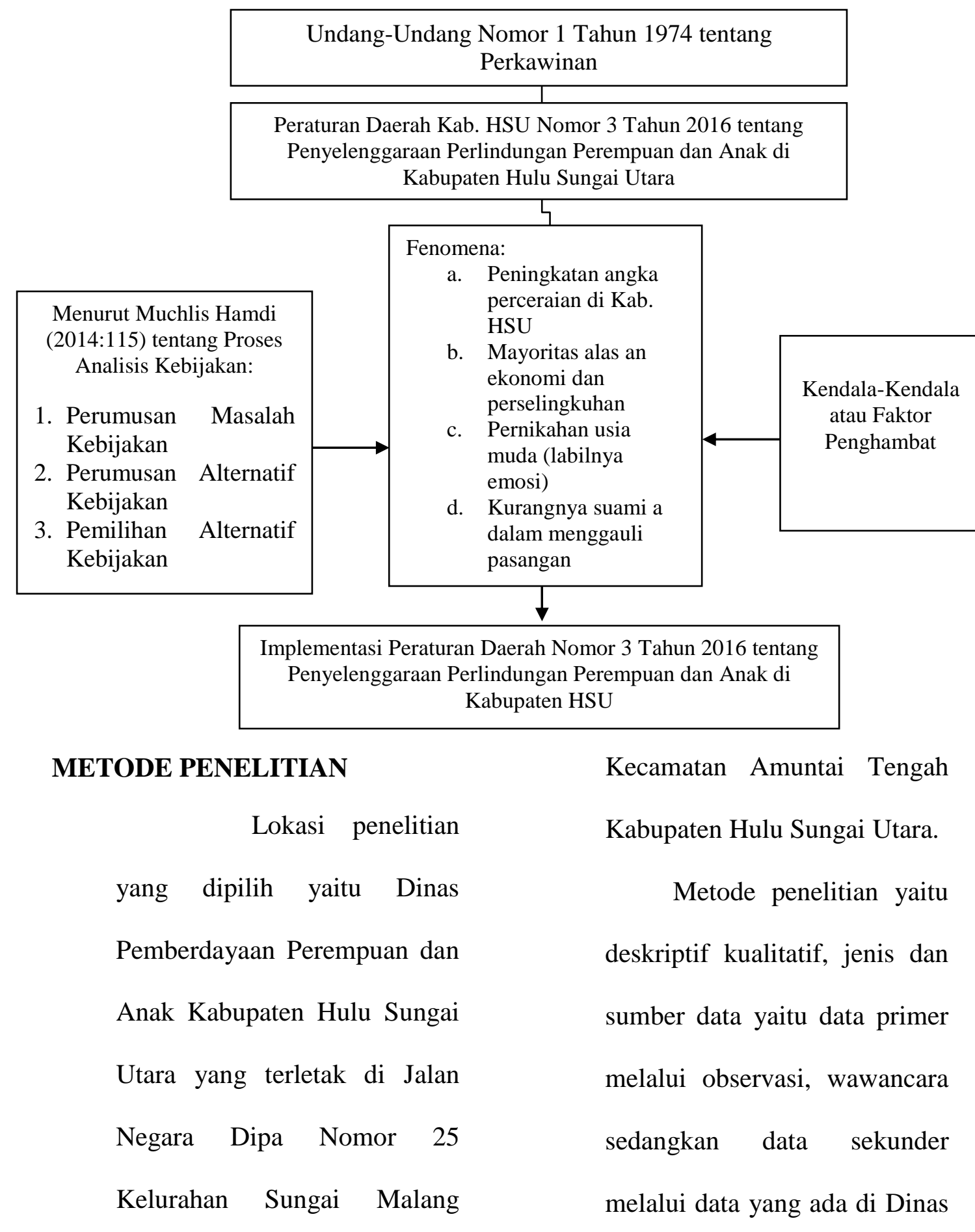


Perlindungan dan

Pemberdayaan Perempuan dan

Anak Kabupaten Hulu Sungai

Utara, teknik yang digunakan

dalam penarikan sampel yaitu

Teknik purposive sampling

adalah penarikan sample secara

bertujuan atau dapat ditentukan

sediri sesuai persyaratan (sifat-

sifat, karakteristik, ciri,

kriteria). Teknik purposive

sampling adalah penarikan

sample secara bertujuan atau

dapat ditentukan sediri sesuai

persyaratan (sifat-sifat,

karakteristik,

ciri,

kriteria).Dalam penelitian ini

informan, yaitu :

1. Kepala Dinas 1 Orang

Kabid.

2.

Perlindungan

1 Orang

Perempuan

dan Anak
3. Kasi

1 Orang

Perlindungan

Perempuan

Kepala UPT

Orang

Perlindungan

4.

Perempuan

dan Anak

5. Ketua

Pengurusan

Kasus

Perlindungan 1 Orang

Perempuan

dan Anak

6. Masyarakat 5 Orang

Jumlah $\quad 10$ Orang

\section{HASIL DAN PEMBAHASAN}

1. Implementasi Peraturan Daerah Nomor 3 Tahun 2016 Tentang Penyelenggaraan Perlindungan Perempuan dan Anak di Kabupaten Hulu Sungai Utara

a. Perumusan Kebijakan

1) Solusi yang tepat

Berdasarkan hasil wawancara dan hasil observasi didapati kesimpulan bahwa Perda Nomor 3 Tahun 2016 tentang Penyelenggaraan Perlindungan

Perempuan dan Anak di 
Kabupaten Hulu Sungai

Utara masih belum memberikan solusi untuk penanganan kasus bagi perlindungan perempuan dan anak di Kabupaten Hulu Sungai Utara.

2) Manfaat kebijakan

Dari beberapa hasil wawancara dan hasil observasi diperoleh kesimpulan bahwa Perda Nomor 3 Tahun $2016 \quad$ tentang Penyelenggaraan

Perlindungan

Perempuan dan Anak di Kabupaten Hulu Sungai Utara belum sepenuhnya manfaat kebijakan tersebut terlaksana dengan baik atau belum semua masyarakat yang berhak mendapatkan perlindungan merasakan dampak positif.

3) Analisis stakeholder

Dengan hasil wawancara dan hasil observasi didapat kesimpulan bahwa dengan Perda Nomor 3 Tahun 2016 tentang Penyelenggaraan Perlindungan Perempuan dan Anak di Kabupaten Hulu Sungai
Utara banyak masyarakat yang belum tahu ataupun belum faham dengan kebijakan tersebut, sehingga sebagian besar masyarakat kurang peduli.

b. Perumusan

Alternatif Kebijakan

1) Tujuan

Berdasarkan hasil wawancara dan hasil observasi diperoleh kesimpulan bahwa Perda Nomor 3 Tahun 2016 tentang Penyelenggaraan Perlindungan Perempuan dan Anak di Kabupaten Hulu Sungai Utara adalah masih belum memberikan tujuan yang tepat sebagai solusi atau alternatif kebijakan dalam mengayomi masyarakat yang membutuhkan

pertolongan khususnya perepuan dalam kekerasan rumah tangga dan anak terakibat perceraian orang tuanya.

2) Biaya

Dari hasil wawancara dan hasil observasi didapat kesimpulan bahwa Perda Nomor 3 Tahun 2016 tentang 
Penyelenggaraan

Perlindungan

Perempuan dan Anak di

Kabupaten Hulu Sungai

Utara bahwa biaya

untuk kebijakan

tersebut cukup besar

karena disesuaikan

dengan kondisi di

lapangan.

3) Kendala

Berdasarkan hasil wawancara dan hasil observasi diperoleh kesimpulan bahwa

Perda Nomor 3 Tahun

2016 tentang

Penylenggaraan

Perlindungan

Perempuan dan Anak di

Kabupatenn Hulu

Sungai Utara terkait permasalahan anggaran dana dalam realisasinya dan sarana prasarananya sebagai kendala.

c. Pemilihan Alternatif

Kebijakan

1) Efisiensi dan efektivitas

Dengan hasil

wawancara dan hasil

observasi didapat

kesimpulan bahwa

Perda Nomor 3 Tahun

$2016 \quad$ tentang

Penyelenggaraan

Perlindungan

Perempuan dan Anak di

Kabupaten Hulu Sungai

Utara adalah belum memberikan solusi dan

alternatif dalam

mengayomi masyarakat

yang memerlukan

perlindungan

(perempuan dan anak)

sehingga belum efisien

dan efektif.

2) Kecukupan

Dari hasil wawancara

dan hasil observasi

dipeoleh kesimpulan

bahwa Perda Nomor 3

Tahun 2016 tentang

Penyekenggaraan

Perlindungan

Perempuan dan Anak di

Kabupaten Hulu Sungai

Utara memang belum

sepenuhnya

memberikan kecukupan

dalam penyelesaian

masalah di masyarakat

terutama masalah

kekerasan terhadap

perempuan dalam

rumah tangga.

3) Keadilan

Berdasarkan hasil

wawancara dan hasil

observasi didapat

kesimpulan bahwa

Perda Nomor 3 Tahun

2016 tentang

Penyelenggaraan

Perlindungan

Perempuan dan Anak di

Kabupaten Hulu Sungai

Utara adalah belum

bisa memberikan

keadilan bagi 
masyarakat korban

kekerasan dalam rumah tangga atau perceraian.

2. Hambatan

dalam

Implementasi Peraturan

Daerah Nomor 3 Tahun 2016

tentang Penyelenggaraan

Perlindungan Perempuan

dan Anak di Kabupaten

Hulu Sungai Utara

Berdasarkan hasil wawancara dan hasil observasi dalam Implementasi Perda Nomor 3 Tahun 2016 tentang Penyelenggaraan Perlindungan Perempuan dan Anak di Kabupaten Hulu Sungai Utara bahwa diperolah kesimpulan bahwa ada 2 (dua) hambatan sehingga kebijakan tersbutn belum optimal, yaitu pertama masalah biaya yang kurang, dan kedua masalah sarana atau tempat konseling untuk penanganan kasus kekrasam dalam rumah tangga bagi perempuan dan dampak perceraian bagi anak.

\section{KESIMPULAN}

Dalam

Implementasi

Peraturan Daerah Nomor 3

Tahun $2016 \quad$ tentang

Penyelenggaraan Perlindungan
Perempuan dan Anak di

Kabupaten Hulu Sungai Utara, masih belum sepenuhnya dijalankan hal ini terlihat dimana penanganan kasus ini belum berjalan dengan sepenuhnya, kemudian masyarakat yang jadi korban kekerasan rumah tangga atau dampak perceraian mereka tidak semuanya tahu tentang peraturan daerah tersebut makanya belum berjalan secara tepat, efisien dan efektif. Sehingga ketegasan dalam penanganan kasus tersebut juga belum bisa dijalankan karena sanksinya tidak disebutkan dan perlu diperbaharui lagi isi kebijakannya.

Kendala atau hambatan yang dihadapi dalam implementasi ini adalah mengenai masalah dana itulah yang menyebabkan tidak adanya 
penanganan kasus lebih lanjut.

DAFTAR PUSTAKA

Selain itu juga kurangnya sarana pendukung seperti tempat konseling dalam penanganan kasus kekerasan dalam rumah tangga atau dampak dalam perceraian masyarakat yang ada di Kabupaten Hulu Sungai Utara.

\section{SARAN}

a. Menyediakan tempat untuk konseling dan pengaduan masalah kekerasan dalam rumah tangga khususnya untuk perlindungan perempuan dan anak;

b. Harus adanya perhatian dan dukungan dari Bupati Hulu Sungai Utara terkait masalah pemberian anggaran dana dalam hal menunjang penanganan kasus perlindungan perempuan.

Buku-buku

Anggara, Sahya., Dr. M.Si. 2014. Kebijakan Publik. Bandung. CV. Pustaka Setia.

Fischer, Frank. Miller, Gerald.J. Sidney, Mara.S. 2015. Hand Book Analisis Kebijakan Publik (Teori, Politik dan Metode). Bandung. Nusa Media.

Hamdi, Muchlis., Prof. MPA, Ph.D. 2014. Kebijakan Publik (Proses, Analisis dan Partisipasi). Bogor. Ghalia Indonesia.

Moelong, Lexy. J. 2007. Metodologi Penelitian Kualitatif. Bandung: PT Remaja Rosdakarya.

Subarsono,

AG.Drs.,M.Si.,MA.

2013. Kebijakan

Publik (Konsep, Teori, dan Aplikasi). Yogyakarta. Pustaka Pelajar.

Sugiyono. 2011. Metode Penelitian Kuantitatif Kualitatif dan R\&D. Bandung: Alfabeta. 
Winarno,

Prof.Drs.MA.PhD.

2014. Kebijakan

Publik, Teori, Proses, dan Studi

Kasus.Yogyakarta.

PT. Buku Seru.

\section{Peraturan-peraturan}

Anonim. 1974. UndangUndang RI Nomor 1 Tahun 1974 Tentang Perkawinan

----------, 2016. Peraturan Daerah Kabupaten HSU Nomor 3 Tahun 2016 tentang

Penyelenggaraan

Perlindungan

Perempuan dan Anak di Kabupaten Hulu Sungai Utara

\section{Jurnal}

Kasih, A. Besse Suci Rezki. 2017. "Perceraian dan Implikasinya terhadap Psikologi Anak di Kecamatan Lalabata Kabupaten Soppeng”. Universitas Islam Negeri Makasar.
Rahmania, Nur Farikha. 2016. "Implementasi Peraturan Pemerintah Tentang Pelaksanaan Perceraian Bagi Pns Pp No. 10 Tahun 1983 Jo. Pp No. 45 Tahun 1990 (Studi Kasus di Pengadilan Agama Surakarta)".

Universitas

Muhammadiyah

Surakarta.

\section{Internet}

Indarani, Nurvita. 2018. “ Dampak Perceraian dan Solusinya". http:///www.psikologi mania.com. 25 Juli 2018 .

Rosyida, Izzatur. 2017. "Dampak Perceraian dan Solusi mengurangi dampak buruk pasca perceraian". http:///www.psikologi mania.com. 20 Maret 2017.

Teguh. 2017. "Pengertian Implementasi Menurut Para Ahli, KBBI, Beserta Contohnya”. http://www.satujam.co m. 2 Agustus 2017. Jakarta. 